\title{
The development of sasi laut in the preservation of sea in Kei community
}

\author{
Sri Wahyu Ananingsih ${ }^{1, *}$ \\ ${ }^{1}$ Faculty of Law, Diponegoro University
}

\begin{abstract}
Sasi laut" is a local wisdom of Kei society that prohibits community members to take natural resources in a particular area over a period of time. Sasi laut has an important role in the preservation of the sea. This article is based on research. The purpose of the research is to analyze causal factors of sasi laut are not practiced anymore in Kei kecil society, and the efforts to revitalize sasi laut as a local wisdom to preserve sea. This article uses socio-legal approach and the analys is is qualitative. The data consist of primary and secondary data. The results of the research show that sasi laut in several villages of Kei kecil is not practiced anymore because of the damage to sea and ecosystem, market problem, the society problem and adat institution problem. The efforts to revitalize sasi laut are improve the quality of the sea environment, legal awareness Kei society and the participation of local government. This article can be a recommendation for the local government of Southeast Maluku in order to determine the policy of sasi laut.
\end{abstract}

\section{Introduction}

Sasi laut is known in Indonesia as one of local wisdom Indonesian people. The regions which still recognize and practice sasi laut tradition i.a : Raja Ampat (Papua), Haruku Island, Seram Island, Aceh Island, Saparua Island, and Kei Island. Sasi laut is a traditional resource management institution. The implementation of it is dynamic through time [1]. Sasi laut can be defined as a set of rules or regulations that govern resource use. It regulates the use of poisonous plants and other chemicals destructive nets and gear, access to the sasi-governed areas, activities that are permitted and seasonal rules of entry and the harvest and other aspects of fisheries [2] [3]. It can be said as a ban on the use of the specific period [4]. The period of time of sasi laut depends on the availability of resources and the needs of the society. They usually have a prediction to decide the time to take resources in sasi laut areas. For example in Nolloth, the time to take lola (throcus Niloticus) resources as the object of sasi laut is whenever the shell has reached the minimum diameter of 6 centimeters [5]. Sasi laut is also an effort to maintain the pattern of social life of the community through the equal distribution of the benefits from the harvest of sasi [6].

Sasi laut is an important institution to preserve the sea. For the period of time, the objects of sasi are prohibited from retrieving by anyone. The aim of sasi is the natural resources will grow optimally and the sea ecosystem can be protected from damage which caused by over exploitation. These reasons have proved by Mc.Leod et al. with their research that the villages that still maintain the practice of sasi have better sea resource conditions than villages which have already disappear the practice. Besides that, sasi laut also gives profit for the community because they will get a part of the harvest. But in fact, although sasi laut has survived over approximately 400 years, it is in the process of dying out in some areas of Maluku province [7]. The same statement is also stated by Craig Thorburn:

.....although increasing domestic and international awareness and praise of sasi, the institution is in decline in many parts of the Moluccas. This is evidenced by many islands no longer practiced at all [8].

In another place, like in Tanimbar Kei, sasi laut is still practiced, but has a change in the system from local knowledge to scientific rational [9]. Likewise in Kei community, the practice of sasi laut is in decline, especially in Kei kecil. The research was conducted to analyze the causal factors of sasi laut are not practiced anymore in Kei kecil community and the efforts to revitalize sasi laut as a local wisdom to preserve sea in Kei Island. Although many articles described sasi laut i.a Franz von Benda Beckmann et al.(1992); Kissya (1995); Craig C. Thorburn (1998); Irene Novaczek, et al.(2001); Nils Bubandt (2005) and Paulus Boli et al. (2014) but they have a different focus of study.

\section{Method}

This research was conducted in Kei Island, Southeast Maluku Regency, Indonesia. The framework of this research analyzes the causal factors sasi laut is not practiced anymore in Kei kecil society and the efforts to

\footnotetext{
*Corresponding author: ayu fhundip@yahoo.com
} 
revitalize sasi laut as a local wisdom to preserve sea in Kei Island. The data consist of primary and secondary data. Primary data were collected by observation, questionnaire and interview. Questionnaire and interview are conducted to gain information about the reason that sasi laut is not applied in Kei kecil, the prospect of sasi laut to preserve sea and the effort of local government and kei society to revitalize sasi laut. The method of questionnaire is used for 50 respondents of Kei kecil while interview for the head of ratshap danar, tubab yamlim, and rumadian (ratshap is combination of several villages (ohoi) in Kei), the head of Kei kecil sub-district, the head of maritime and fisheries office in Kei district, Ngo activist and the tetua adat in Kei. Secondary data were collected by literature study. The data were analyzed with qualitative analysis.

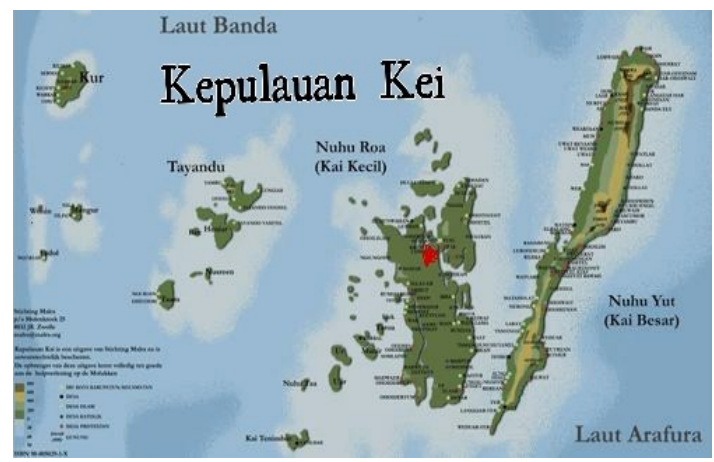

Fig 1. Kei Is land

\section{Result and discussion}

\subsection{The causal factors of sasi laut are not practiced in Kei society}

Kei Island consists of kei besar (Nuhu Yut) and kei kecil (Nuhu Roa).See Fig.1. Kei besar is a highland area. People can reach this region by ship from Kei kecil and then continued by land transportation. Meanwhile Kei kecil can reach more easily than Kei besar. It just reached by land transportation. That's one of reasons why people in Kei kecil receive more external influence than people in Kei besar. The social life of Kei kecil community also looks more modern than Kei besar community.

Sasi laut is recognized in Kei besar as "Yot" and in Kei kecil as "Yutut". Both of Kei besar and Kei kecil are in Southeast Maluku regency. This region has a heterogeneous potential of marine resources, because it is flanked by the Arafura Sea Islands, Banda sea and the territory of Papua and Australia. Sasi laut is based on customary law and managed by adat institution. This institution has the task to plan, announce and prepare ritual of sasi laut. They also keep track of the practice of sasi laut. Sasi laut is marked by a young coconut leaf which tied up to a piece of wood (people kei named as ainum wood) in the area of sasi. People are prohibited to take resources in the area during the time of sasi. If they find a violation, they inform to the head of the village. The violator will be prosecuted to adat court. If he is proven guilty, the head of the village or the head of ratshap (Kei people called it "Raja") will determine adat sanction for him.

In the past, objects of sasi laut were all kinds of fish. But since 2000-2001, the objects are just throcus niloticus (lola) and sea cucumber because they are marketable in export markets. Related with the duration of sasi laut, at this time, it is longer than in the past. Sasi laut usually needs time 1 to 5 year [10].

Villages in Kei kecil no longer practicing sasi laut because 4 factors. They are:

Table 1. The factors cause villages in Kei kecil do not maintain sasi laut

\begin{tabular}{|l|l|l|}
\hline No. & \multicolumn{1}{|c|}{ Factors } & \multicolumn{1}{c|}{ Problem } \\
\hline 1 & $\begin{array}{l}\text { Sea and its } \\
\text { ecosystem }\end{array}$ & $\begin{array}{l}\text { Sea and it's ecosystem damage. They } \\
\text { usually caused by the use of poisonous } \\
\text { plants, other chemicals, destructive nets } \\
\text { and gear. Consequently, lola and sea } \\
\text { cucumber can not life optimally. }\end{array}$ \\
\hline 2 & Market & $\begin{array}{l}\text { A difficulty in selling the harvest of sasi } \\
\text { laut. }\end{array}$ \\
\hline 3 & $\begin{array}{l}\text { The } \\
\text { community }\end{array}$ & $\begin{array}{l}\text { They do not support to maintain the } \\
\text { tradition of sasi laut. }\end{array}$ \\
\hline 4 & $\begin{array}{l}\text { Adat } \\
\text { institution }\end{array}$ & $\begin{array}{l}\text { Adat institution has not authority } \\
\text { anymore. }\end{array}$ \\
\hline
\end{tabular}

The four factors are related to each other, but the majority of respondents have the same opinion that the main factor sasi laut is not practiced in villages of Kei kecil is sea and ecosystem problem. It is the first of problem. It is caused by the use of poisonous plants, other chemicals, destructive nets and gear. The most fishermen who use poisonous plants and other chemicals, destructive nets and gear are outsiders, are outsiders. They want to get large amounts of fish so they use poisonous plants, other chemicals, destructive nets and gear. Surely, it is a violation of adat law. Second, market problem. It is a difficulty in harvest management of sasi laut. The community has difficulty to find buyers for the harvest. The buyers usually have criteria in determining the size of lola and sea cucumber. On the contrary, if the harvest of sasi are not conform the size, they are not sold out. Third, the attitude of Kei kecil people have change nowadays. Kei people begin do not care about the sustainability of sasi laut and customary law. The majority of them are young generation of Kei kecil. The passiveness of them are often caused by influence foreign culture. Fourth, adat institution problem. Although adat institution still exists in Kei, but the authority is reduced, including the control system of sasi laut.

\subsection{The efforts to revitalize sasi laut in Kei}

Sasi laut is an important institution and give economic benefit to community so it must be maintained its 
existence. Especially in Kei kecil. there are some efforts to revitalize sasi laut. The efforts of the local government are first, give socialization about the importance of the role of sasi in preserving sea resources and ecosystem to the community, especially young generation of Kei kecil. This activity can be realized through coordination with Fisheries and Marine office and education and culture. Second, increase the role of Fisheries and Marine office in the development of sustainable natural resources in Kei.

It is very important because all the time, they just behave passive role. In this case, the local government must be active. Third, the strengthening of adat institution through intensive communication with the adat leaders. It means adat institution as the main institution must exist in Kei kecil so it support sasi laut and its sustainability. Fourth, improve legal awareness of Kei society. Fifth, improve society empowering in natural resources management. Sixth, overcoming difficulties in determining buyers for selling the harvest of sasi laut. The efforts of community of Kei kecil to revitalize sasi laut are preserved sea and its ecosystem. The way to actualize that aim are prevented the use of poisonous plant and chemicals, destructive net and gear in fishing, enforce regulation of sasi laut and set adat sanction to violators.

\section{Conclusion}

Sasi laut is an important traditional institution, especially to preserve sea and its ecosystem. It means that sasi laut must be maintained in Kei kecil. Villages are not practice of sasi laut anymore in Kei kecil because 4 factors: sea and ecosystem problem, market problem, the community problem and adat institution problem. The efforts to revitalize sasi laut include give socialization about the importance of the role of sasi in preserving sea resources and ecosystem to the community, increase the role of Fisheries and Marine office in the development of sustainable natural resources in Kei, the strengthening of adat institution through intensive communication with the adat leaders, improve legal awareness of Kei society, improve society empowering in natural resources management and overcoming difficulties in determining buyers for selling the harvest of sasi laut.

\section{References}

1. C. Zerner, Law Soc. Rev., vol. 28, no. 5, p. 1079, (1994).

2. Gerd Winter (ed), IUCN Environmental Law Centre, Germany, 74, (2009).

3. I. Harkes, in Proceedings of the International Workshop on Fisheries Co-management, p. 1, (2001)

4. B. A. Benda-Beckmann Fronz, Benda-Beckmann Keebet, (1992).

5. R. V. Rugebregt, Faculty of Law Pattimura University. [Online]. Available: http://fhukum.unpatti.ac.id/artikel/hukum-tatanegara/45-revitalization-of-the-role-of-kewanginstitute-in-traditional-government-system-ofnatural-resource\#_ftnref21.

6. Kissya, Sasi Aman Haru-Ukui. Jakarta: Sejati, (1994).

7. I. Novaczek, I. Harkes, J. Sopacua, ICLARM, (2001).

8. T. Craig, Indones. J. Coast. Mar. Resour., vol. 1, no. 2, pp. 57-68, (1998).

9. Jayanti and Osozawa, J. Perikan. (Journal Fish. Sci., vol. XV, no. 1, p. 43, (2014).

10. S. W. Ananingsih, Universitas Gadjah Mada, (2015). 